Paedagogia Christiana

2/30 (20I2) - ISSN I505-6872

Wojciech Osial*

Łowicz

\title{
Wychowawczo-aksjologiczne aspekty misji nauczyciela
}

Temat wychowawczych zadań nauczyciela w polskim systemie oświaty wydaje się być wciąż aktualny i potrzebny w refleksji nad procesem wychowania młodego człowieka. Wiele na ten temat już napisano, wskazując na różnorodne kierunki i płaszczyzny poszukiwań i działań oświatowych. Niewątpliwie jest to problem bardzo złożony i wieloaspektowy, który wskazuje na bogactwo różnych wymiarów wychowawczej misji nauczyciela w szkole. Podjęta refleksja stanowi próbę spojrzenia na zadania i obowiązki wychowawcze nauczyciela w kontekście procesu wychowania ucznia w wartościach i do wartości. Ma się na uwadze węższe znaczenie wychowania. Chodzi o kształtowanie charakteru człowieka, w którym jego wola zostaje skierowana na wartości i cele moralne. Jest to obszar uaktywnienia przeżyć emocjonalno-motywacyjnych ucznia i kształtowania zachowań i postaw moralnie i społecznie pożądanych ${ }^{1}$. Wartości są ujmowane w ich pedagogicz-

* Ks. dr Wojciech Osial, wykładowca w Wyższym Seminarium Duchownym w Łowiczu i Wyższym Seminarium Duchownym w Ołtarzewie, rzeczoznawca do spraw oceny programów nauczania religii Komisji Wychowania Katolickiego Konferencji Episkopatu Polski.

Zob. M. Łobocki, W trosce o wychowanie w szkole, Kraków 2009, s. 32. Warto w tym kontekście przypomnieć, że w literaturze nie ma jednego ścisłego pojęcia wychowania, szczególnie w jego węższym znaczeniu. Należy przyjąć wielość definicji wychowania. Wszystkie definicje w znaczeniu węższym akcentują w jakiś sposób kształtowanie pożądanych cech moralnych i społecznych wychowanka. Mamy tutaj do czynienia z wyraźnym postawieniem problemu wartości i otwarciem się na perspektywę aksjologiczną (Zob. M. Łobocki, Teoria wychowania w zarysie, Kraków 2009, s. 31-35; M. Nowak, Podstawy pedagogiki otwartej. Ujęcie dynamiczne w inspiracji chrześcijańskiej, Lublin 2001, s. 272). Tak rozumiane wychowanie jest częścią wychowania w jego szerszym znaczeniu, które oznacza „wszelkie oddziaływania na 
nym wymiarze i oznaczają wszystko to, co jest pragnieniem człowieka, co nie zagraża ładowi moralnemu, co łączy się z pozytywnymi odczuciami i co jest celem jego dążeń. Chodzi o wartości uznawane za fundament życia społecznego i osobistego ${ }^{1}$. Wyraża się nadzieję, że tak sformułowany kierunek refleksji może stać się pomocą dla pogłębienia wychowawczej pracy dzisiejszego nauczyciela. Podjęty temat może być też inspiracją dla twórczego odczytywania zapisów o obowiązkach wychowawczych nauczyciela zawartych w dokumentach polskiego systemu oświaty. Chodzi przede wszystkim o lekturę zapisów i wskazań zawartych w Ustawie Karta Nauczyciela z dnia 26 stycznia 1982 roku wraz z późniejszymi zmianami. Jest to najważniejszy dokument określający prawa i obowiązki nauczyciela w polskim systemie oświaty ${ }^{2}$.

\section{Szkoła nie tylko uczy, ale i wychowuje}

Twierdzenie, że szkoła nie tylko uczy, ale i wychowuje, wydaje się być rzeczą oczywistą i przez wszystkich akceptowaną. Przyjmuje się, że wychowawcza funkcja nauczyciela stanowi obok funkcji dydaktycznej i opiekuńczej integralną część jego pracy w szkole. Szkoła jest uznawana za drugie zaraz po rodzinie podstawowe środowisko wychowawcze. Definiując szkołę stwierdza się, że „szkoła to instytucja oświatowo-wychowawcza zajmująca się kształceniem i wychowywaniem dzieci, młodzieży i dorosłych, stosownie do przyjętych w danym społeczeństwie celów i zadań oraz koncepcji oświatowo-wychowawczych”’3. Istnieje więc określony kanon postrzegania

człowieka, współtworzące jego osobową indywidualność" (Zob. M. Nowak, dz. cyt., s. 272). Jest to proces skoncentrowany na rozwoju osobowości w jej wszystkich cechach. Chodzi więc o zmiany zarówno w wymiarze poznawczo-instrumentalnym (poznawanie rzeczywistości i umiejętność oddziaływania na nia), jak i w wymiarze emocjonalno-motywacyjnym (kształtowanie stosunku człowieka do świata i ludzi, jego przekonań i postaw, układu wartości i celu życia). Zob. W. Okoń, Nowy stownik pedagogiczny, Warszawa 2007, s. 466.

${ }^{1}$ Zob. M. Łobocki, Wychowanie moralne w zarysie, Kraków 2006, s. 72; M. Nowak, dz. cyt., s. 393-395.

${ }^{2}$ Ustawa z dnia 26 stycznia $1982 \mathrm{r}$. Karta Nauczyciela. Tekst opracowany na podstawie: Dziennik Ustaw 2006 r. Nr 97, poz. 674, Nr 170, poz. 1218, Nr 220, poz. 1600, z 2007 r. Nr 17, poz. 95 , $\mathrm{Nr} 80$, poz. 542,102 , poz. 689 , Nr 158 , poz. 1103 , Nr 176, poz. 1238 , Nr 191 , poz. 1369, Nr 247, poz. 1821, z 2008 r. Nr 145, poz. 917, Nr 227, poz. 1505, z 2009 r. Nr 1, poz. $1, \mathrm{Nr} 56$, poz. $458, \mathrm{Nr} 67$, poz. 572 (dalej cyt. KN). Ustawa o systemie oświaty z 1991 roku praktycznie pomija kwestie praw i obowiązków nauczyciela i odsyła w tym temacie do Karty Nauczyciela. Zob. Ustawa z dnia 7 września 1991 roku o systemie oświaty z późniejszymi zmianami, w: Dz. U. Nr 56, poz. 458 (zmiany z 19 marca 2009), art. 5 b.

3 W. Okoń, Nowy stownik, s. 402. 
szkoły jako instytucji o funkcji zarówno dydaktycznej jak i wychowawczej. Wychowawcza misja szkoły jest szeroko omawiana w literaturze pedagogicznej4. Jest ona również przywołana $\mathrm{w}$ dokumentach prawnych polskiego systemu oświaty. W podstawach programowych dla każdego typu szkoły publicznej mówi się o wychowaniu i systemie wartości stojących u jego podstaw oraz sugeruje się drogi realizacji tego wychowania ${ }^{5}$. Od szkół wymaga się programów wychowawczych i profilaktycznych, które podlegają formalnej kontroli ${ }^{6}$. Rozporządzenia o nadzorze pedagogicznym określają standardy w dziedzinie wychowania, opieki i profilaktyki. W sytuacji braków i trudności wymaga się programów naprawczych. W rozporządzeniu w sprawie warunków i sposobu oceniania określa się precyzyjnie, co podlega ocenie w zachowaniu ucznia ${ }^{8}$. Można więc stwierdzić, że całość tej bogatej refleksji i prawa oświatowego stanowi mocną stronę dzieła wychowania w szkole, ale jednocześnie nie można też nie widzieć wielu głosów krytycznych pod adresem funkcjonowania wychowawczych zadań szkoły w całej strukturze systemu oświaty9.

Spoglądając na konkretną rzeczywistość życia szkoły, można jednak stwierdzić, że ta słuszna teoria dostrzegająca wychowawczą funkcję szkoły nie zawsze jest dostatecznie realizowana czy zauważalna w praktyce szkolnej. Wymiar regulacji prawnych oraz bogata refleksja pedagogiczna wydają się nie wystarczać. Wszyscy podzielają potrzebę wychowania, uzasadniają jego szczególną rolę w rozwoju człowieka, niemniej jednak w praktyce prawdy te nie zawsze są odpowiednio realizowane. Wydaje się, że funkcja

${ }^{4}$ Zob. M. Dudzikowa, Mit o szkole jako miejscu wszechstronnego rozwoju ucznia. Eseje etnopedagogiczne, Kraków 2004; M. Łobocki, W trosce; tenże, Wybrane problemy wychowania nadal aktualne, Lublin 2004; S. M. Kwiatkowski (red.), Nowe uwarunkowania edukacji szkolnej, Warszawa 1997; W. Okoń, Wszystko o wychowaniu, Warszawa 2009; B. Śliwerski, Program wychowawczy szkoty, Warszawa 2001; M. Dudzikowa, M. Czerepaniak-Walczak (red.), Wychowanie. Pojęcia. Procesy. Konteksty, t. I-V, Gdańsk 2007-2010.

${ }_{5}$ Zob. Rozporządzenie Ministra Edukacji Narodowej z dnia 23 grudnia 2008 roku w sprawie podstawy programowej wychowania przedszkolnego oraz kształcenia ogólnego w poszczególnych typach szkół, Dz. U. z dnia 15 stycznia 2009, Nr 4, poz. 17. Zał. 1-7.

${ }^{6}$ Zob. tamże.

7 Zob. Rozporządzenie Ministra Edukacji Narodowej z dnia 7 października 2009 roku w sprawie nadzoru pedagogicznego, Dz. U. z dnia 9 października 2009 r.

${ }^{8}$ Zob. Rozporządzenie Ministra Edukacji Narodowej z dnia 30 kwietnia 2007 r. w sprawie warunków i sposobu oceniania, klasyfikowania i promowania uczniów i słuchaczy oraz przeprowadzania sprawdzianów i egzaminów w szkołach publicznych, Dz. U. Nr 83, poz. 562 , z późn. zm.

9 Zob. M. Dudzikowa, dz. cyt.; J. Pielachowski, Mocne i stabe strony wychowania w szkole. (Nie)prześmiewcze refleksje dtugoletniego praktyka, w: M. Dudzikowa, M. Czerepaniak-Walczak (red.), dz. cyt., t. III, Gdańsk 2007, s. 233-262. 
dydaktyczna szkoły dużo mocniej wybrzmiewa w spojrzeniu na rzeczywistość szkolną. Preferowanie przez szkołę funkcji kształcenia uważa się za bardzo poważne niedomaganie funkcjonowania dzisiejszej szkoły ${ }^{10}$. Takie niebezpieczeństwo można uważać za bardzo realne. Często organy nadzorujące oświatę, a także i sami rodzice, dużo bardziej zawracają uwagę na wiedzę i umiejętności dziecka niż jego wychowawcze i moralne postawy. Na skuteczność pracy nauczyciela patrzy się częściej poprzez osiagnięcia uczniów w testach kompetencyjnych i egzaminach końcowych niż przez włożone wysiłki w wychowanie do postaw. Znakiem przypisywania dużej wagi kształceniu są również coroczne rankingi szkół, które w swoich kryteriach przywołuja jedynie osiagnięcia dydaktyczne a nie wychowawcze. Podobne nastawienie dostrzega się w postawach rodziców, którzy chcą, aby ich dzieci były mądre, miały wysokie oceny i dostawały się na kierunki studiów zapewniające wysokie standardy przyszłego dorosłego życia. Kwestie wychowawcze rodzice często zastrzegają jedynie sobie i nierzadko też spierają się o kompetencje wychowawcze z nauczycielem-wychowawcą. Wydaje się więc, że zagadnienia wychowawcze, chociaż nie są negowane, co więcej w teorii nawet uznawane za ważne, to jednak w praktyce życia ustępują miejsca ważności wiedzy i osiagnięciom intelektualnym ucznia.

Wychowanie tymczasem winno zajmować szczególną rolę w szkole. Konieczne jest, aby należycie dostrzec i dowartościować wychowawczą funkcję szkoły. W jej realizacji bardzo ważna jest postawa samego nauczyciela. Słusznie stwierdza M. Łobocki, że niezwykłe znaczenie dla skuteczności wychowania ma

przywiązanie przez nauczycieli doniosłej wagi do pełnienia funkcji stricte wychowawczej, w tym zwłaszcza kształtowanie postaw społeczno-moralnych uczniów, a nie koncentrowanie się wyłącznie na sprawowaniu funkcji kształcącej, czyli głównie na przekazywaniu im wiedzy, rozwijaniu zdolności i egzekwowaniu zdobytych przez nich wiadomości szkolnych w zakresie poszczególnych przedmiotów nauczania ${ }^{11}$.

Niestety często zauważa się preferowanie funkcji kształcącej ze szkodą dla funkcji wychowawczej. Przyczynami takich postaw są między innymi przeładowane programy nauczania, hołdowanie tradycyjnym metodom nauczania (werbalizm i uczenie na pamięć), stosowanie przestarzałych form organizacji samego procesu nauczania i uczenia się (nauczanie frontalne

${ }^{10}$ Zob. M. Łobocki, Teoria, s. 308; tenże, Wybrane, s. 66-78.

${ }^{11}$ Tenże, $W$ trosce, s. 11-12. 
z koncentracją na podręczniku i nauczycielu) ${ }^{12}$. Warto dodać, że przyglądając się realiom szkoły można niestety zauważyć i taką sytuację, w której duża liczba wymagań dydaktycznych i biurokratycznych wobec nauczyciela sprawia, że posiada on coraz mniej czasu na wychowanie i osobisty kontakt z uczniem. Z pewnością nie jest to sytuacja sprzyjająca wychowaniu. W takiej sytuacji jedyną możliwą rzeczą do wykonania jest starać się napełniać treściami, wartościami i postawami wychowawczymi wszystkie prowadzone przez siebie lekcje. Takie rozwiązanie jednak nie wystarcza. Jest więc poważnym wyzwaniem poszukiwanie dróg umożliwiających i wspierających wszelkie inne dodatkowe działania wychowawcze nauczyciela.

\section{Spór wokół wspólnej wizji wychowania}

W kontekście wychowawczej misji nauczyciela warto zwrócić uwagę na fakt, że w zarządzaniu oświatą rodzą się różnego rodzaju spory wokół wizji wychowania i polityki oświatowej. Wynikają one z różnic ideowych pomiędzy rządzącymi w danym momencie ugrupowaniami politycznymi a ich opozycją. B. Śliwerski zauważa, że

w okresie przemiany społeczno-politycznej III Rzeczypospolitej Polskiej można u przedstawicieli władzy parlamentarnej, samorządowej i rządowej rozpoznać ideologiczne zniekształcenie różnie stanowionego sensu edukacji i wychowania [...]. Nikt nie kwestionował potrzeby inwestowania środków publicznych w kapitał ludzki, jeśli nie mamy stać się tanią, słabo wykwalifikowaną siłą roboczą w Unii Europejskiej bądź nie chcemy pogłębiać stanu wtórnego i funkcjonalnego analfabetyzmu. Jednak sposób, w jaki cały system szkolny powinien się zmieniać, miał swoje odzwierciedlenie w nieco różniących się od siebie projektach, oczekiwaniach czy wręcz roszczeniach różnych stron dyskursu publicznego. Szczególnie mocno są akcentowane w tym względzie różnice ideowe między poszczególnymi nurtami czy partiami politycznymi. Zatem spór o miejsce, rolę i sposób kształcenia oraz wychowania młodego pokolenia nie znika wraz z dojściem do władzy którejś z sił politycznych, a wręcz odwrotnie - potęguje jeszcze potrzebę zaakcentowania swojej odmienności czy stanu niezadowolenia ${ }^{13}$.

${ }^{12}$ Zob. tenże, Wybrane, s. 123-125.

13 B. Śliwerski, Oświatowy remanent, czyli o ideologicznym majsterkowaniu polityków oświatowych w latach 1989-2006, w: M. Dudzikowa, M. Czerepaniak-Walczak (red.), dz. cyt., t. IV, Gdańsk 2008, s. 95-96. Zob. też tenże, Problemy wspótczesnej edukacji. Dekonstrukcja polityki oświatowej III RP, Warszawa 2009. 
Niestety jest to smutna sytuacja, że w III Rzeczypospolitej nie udało się zbudować $\mathrm{w}$ oświacie kompromisu politycznego ${ }^{14}$. Politycy starają się wprowadzić taki styl wychowania, który będzie odpowiadał wyznawanym przekonaniom i wartościom. Bardzo smutna, ale i zarazem prawdziwa, jest ocena ostatnich kilkunastu lat reformy oświaty, według której szkoła, wyzwalając się z sytuacji braku demokracji, zostaje poddawana nowym formom dominacji politycznej i ideologicznej. Brakuje jednego wspólnego i zgodnego stanowiska ponad podziałami politycznymi dla dobra wychowania człowie$\mathrm{ka}^{15}$. Niewątpliwie ten chaos $\mathrm{w}$ organizacji oświaty i w procesie wytyczania kierunków wychowawczych negatywnie oddziałuje na samą pracę nauczyciela i jego motywacje.

\section{Zadanie wychowywania do wartości}

Ustawa Karta Nauczyciela w artykule 6 stwierdza, że nauczyciel zobowiązany jest do podejmowania pewnych obowiązków mających na celu dobro ucznia. Wśród nich wymienia się między innymi zadania nauczyciela o charakterze ściśle wychowawczym odnoszące się do określonych wartości. Są one następujące: rzetelna realizacja zadań związanych wychowawczą funkcją szkoły, wspieranie każdego ucznia w jego rozwoju, kształcenie i wychowywanie w umiłowaniu Ojczyzny, w poszanowaniu Konstytucji Rzeczypospolitej Polskiej, w atmosferze wolności sumienia i szacunku dla każdego człowieka, dbanie o kształtowanie postaw moralnych i obywatelskich zgodnie z ideą demokracji, pokoju i przyjaźni między ludźmi różnych narodów, ras i światopoglądów ${ }^{16}$. Na podstawie przywołanych zapisów można stwierdzić, że powierzane nauczycielowi zadania wskazują na istnienie u ich podstaw jakiegoś określonego systemu wartości.

Nauczyciel winien odczytywać powierzane mu obowiązki zawsze w kluczu wychowania do wartości. Jest to inwestycja w człowieka, która jest godna wszelkiego trudu i zapału. Z pewnością kwestia wartości w wychowawczej misji szkoły jest tematem obszernym i złożonym ${ }^{17}$. Zostaną więc

${ }^{14}$ Zob. tenże, Przemiany edukacji polskiej po 1990 roku. Diagnoza i perspektywy, „Forum oświatowe" 1 (2002), s. 27n.

${ }_{15}$ Zob. B. Śliwerski, Reformowanie oświaty w Polsce, w: Z. Kwieciński, B. Śliwerski (red.), Pedagogika, t. II, Warszawa 2010, s. 383-384.

${ }^{16} \mathrm{KN}$ art. 6, pkt 1-2, 4-5.

${ }_{17}$ Szerzej na ten temat: A. Błasiak, Aksjologiczne aspekty procesu wychowania. Wybrane zagadnienia, Kraków 2009; K. Chałas, Wychowanie ku wartościom. Elementy teorii i praktyki, Lublin-Kielce 2003; W. Cichoń, Wartości - Człowiek - Wychowanie. Zarys problematyki aksjologiczno-wychowawczej, Kraków 1996; M. Nowicka-Kozioł (red.), Człowiek-wartości- 
przybliżone jedynie niektóre kwestie, które wydają się być ważne i aktualne. Akcentowanie potrzeby wartości w wychowaniu jest szczególnie ważne, gdyż we współczesnej refleksji oświatowej nie zawsze te treści właściwie wybrzmiewają. Przykładowo można wskazać na dyrektywy edukacyjne Unii Europejskiej, mające bardzo często charakter mocno pragmatyczny ${ }^{18}$. Z należytą troską należy pochylić się także nad cennymi raportami UNESCO, które akcentują potrzebę zwaloryzowania etycznych aspektów edukacji. Tendencja tego rodzaju jest widoczna chociażby w raporcie Międzynarodowej Komisji do Spraw Edukacji dla XXI wieku pod przewodnictwem J. Delorsa, zatytułowanym Edukacja: jest w niej ukryty skarb (1998) ${ }^{19}$. Można wskazać również na raport F. Mayora z 1999 roku zatytułowany Przyszłość świata (Un monde nouveau ${ }^{20}$. Przebija $\mathrm{w}$ tych raportach głębokie przekonanie, że edukacja ma silny związek z wyborami etycznymi. Tragedie ludzkości spowodowane złymi decyzjami człowieka ukazują konieczność i potrzebę wyborów aksjologicznych. Człowiek potrzebuje dzisiaj pomocy w wychowaniu do podejmowania dobrych decyzji nie tylko prakseologicznych, ale również i etycznych. Dobitnie tę prawdę wyraził Jan Paweł II na spotkaniu UNESCO w 1980 roku, kiedy mówil, że celem wychowania jest to, aby człowiek stawał się coraz bardziej człowiekiem, aby bardziej „był” a nie tylko więcej „miał”, aby również umiał bardziej „być” nie tylko z „drugimi”, ale także $i$ „dla drugich”" Nie wolno zapomnieć o etyce i skoncentrować się jedynie na praktycznym wymiarze życia. W przeciwnym wypadku konsekwencje decyzji człowieka pomijające wybory etyczne mogą okazać się tragiczne. K. Denek stwierdza, że nie da się sensownie traktować edukacji poza systemem wartości, gdyż „wyzwaniom nadchodzącego XXI wieku może sprostać tylko człowiek wielostronnie wykształcony, zdolny do myślenia w kategoriach innowacyjnych i alternatywnych, energiczny, sprawny, wrażliwy na wartości, uznający je za dyrektywy postępowania, drogowskazy życia, czyli

pedagogika, Kraków 2007; K. Denek, Aksjologiczne aspekty edukacji szkolnej, Torun 1999; K. Olbrycht (red.), Edukacja aksjologiczna, t. I, Katowice 1994; M. Lobocki, Wychowanie moralne, s. 71-77; Z. Marek, Podstawy wychowania moralnego, Kraków 2005; K. Olbrycht, Prawda, dobro i piękno w wychowaniu człowieka jako osoby, Katowice 2002; W. Szewczuk (red.), Świat wartości i wychowanie, Warszawa 1996.

${ }_{18}$ Zob. W. Rabczuk, Etyczny wymiar edukacji w świetle raportów UNESCO, w: A. Rumiński (red.), Etyczny wymiar edukacji nauczycielskiej, Kraków 2004, s. 39.

${ }_{19}$ Zob. Edukacja: jest w niej ukryty skarb, Raport dla UNESCO Międzynarodowej Komisji do Spraw Edukacji dla XXI wieku pod przew. J. Delorsa, Warszawa 1998.

${ }^{20}$ Zob. F. Mayor, Przyszłość świata, Warszawa 2001.

${ }^{21}$ Zob. Jan Paweł II, Wychowanie jest pierwszym i zasadniczym zadaniem kultury. Przemówienie w siedzibie Organizacji Narodów Zjednoczonych do Spraw Oświaty, Nauki i Kultury (UNESCO), w: S. Urbański (red.), Wychowanie w nauczaniu Jana Pawła II (1978-1999), Warszawa 2000, s. 130. 
człowiek pełny"22. Warto też tutaj przywołać ważne słowa cytowanego już M. Łobockiego:

współczesne wychowanie do wartości, zwłaszcza uniwersalnych i ponadczasowych, urasta do wyjątkowego ważnego zadania. Dzieje się tak w niemałej mierze w wyniku wyemancypowania się wielu ludzi (szczególnie w Europie Zachodniej) spod dominującego niegdyś wpływu religii zinstytucjonalizowanej. Podobną tendencję zauważa się także na pewną skalę w Polsce. Przejawia się ona $\mathrm{w}$ postępującej z wolna sekularyzacji, niosącej z sobą niekiedy poważne niebezpieczeństwo natury moralnej. Człowiek wszakże, tracąc moralne oparcie w religii, skłonny bywa nie tylko do nieuznawania jakichkolwiek autorytetów moralnych, lecz także wykazuje krytyczny stosunek wobec wszelkich wartości wyższych łącznie z moralnymi. Zdany bywa na wybór wartości według przysłowiowego „widzi mi się”, co skazuje go na bardziej lub mniej skrajny relatywizm moralny. Tym samym łatwo zadowala się bezsensownym usprawiedliwianiem zachowań de facto sprzecznych z moralnością i poczuciem godności osobistej ${ }^{23}$.

Komentarzem apelującym o wartości w dzisiejszej kulturze postmodernizmu mogą być również i te słowa, według których ,nasze uczynki zostały uwolnione od resztek nieskończonych obowiązków, przykazań i absolutnych zobowiązań [...] a samo poświęcenie nie ma już uzasadnienia [...]. Nie wymaga się już od ludzi [...], by wytężali się w imię moralnego samodoskonalenia i obrony wartości moralnych"24. Obecność wartości w wychowaniu decyduje o wartości samego wychowania. Słusznie stwierdza się, że wychowanie pomijające wprowadzanie w świat wartości staje się wychowywaniem jedynie połowicznym i mało skutecznym, a często również i społecznie szkodliwym. Pozbawia ono ucznia możliwości jednoznacznego odróżniania dobra od zła i tym samym nie uczy podejmowania decyzji mądrych i zgodnych z podstawowymi zasadami moralności ${ }^{25}$. Niedocenianie wartości prowadzi do zjawiska brutalizacji życia, zaniku sacrum na rzecz profanum, absolutyzacji życia doczesnego i różnych patologii społecznych ${ }^{26}$. Wymiar aksjologiczny wychowania należy uznać za priorytetowy, gdyż wychowanie oparte na war-

22 K. Denek, Aksjologiczne, s. 23.

23 M. Łobocki, Wychowanie moralne, s. 81.

24 Z. Bauman, Etyka ponowoczesna, Warszawa 1996, s. 7.

25 M. Łobocki, Wychowanie moralne, s. 77.

26 Zob. K. Denek, Wartości i cele edukacji szkolnej, Poznań-Toruń 1994, s. 14-16. 
tościach wpływa na to, kim człowiek jest i w jakim kierunku zmierza jego życie i losy świata ${ }^{27}$.

\section{Ksztaltowanie postaw moralnych i spolecznych}

Wypełnianie zadań nauczycielskich związanych z wychowaniem do wartości wprowadza w niezwykle ważny obszar wychowania moralnego. Nauczyciel, realizując powierzone mu zadania, winien zawsze wychowywać moralnie. Niestety w literaturze pedagogicznej na ten temat wcale za dużo się nie mówi. Wołanie o moralność staje się szczególnie potrzebne w dobie dzisiejszego rozwoju kulturowego i postępu naukowo-technicznego. W dzisiejszym świecie, jak zauważa M. Łobocki, występuje „stępienie wrażliwości etycznej” i dlatego „wychowanie moralne staje się dziś pilną potrzebą, której niezaspokojenie grozi dalszym spadkiem zachowań i postaw moralnych ludzi, a tym samym brakiem szybkiego wyjścia z istniejącego obecnie kryzysu moralnego. Czas więc najwyższy, aby problematyce moralnej poświęcić więcej niż dotychczas miejsca zarówno w teorii, jak i praktyce pedagogicznej" ${ }^{28}$. W innym miejscu ten sam autor stwierdza, że potrzeba wychowania moralnego wynika także z dostępu do programów telewizyjnych ukazujących wiele zła i wyzwalających agresję ${ }^{29}$. Warto w tym kontekście dodać bardzo negatywne aspekty wpływu Internetu na rozwój i postawę uczniów. Współczesna edukacja staje przed powinnością ciagłego formułowania i realizowania zadań wychowania moralnego. Chodzi o to, aby nauczyciel wprowadzał ucznia w świat wartości, pomagał mu odróżniać dobro od zła i wybierać zawsze dobro. Z. Marek w takim duchu formułuje cztery podstawowe zadania wychowania moralnego: odkrywanie i przejmowanie świata wartości, dążenie do dojrzałej osobowości, kształtowanie postaw moralnych i kształtowanie sumienia ${ }^{30}$. Taki integralny obraz zadań formacji moralnej jest jak najbardziej słuszny i potrzebny, aby mówić o pełnym wychowaniu moralnym.

Określenie konkretnych i wspólnych wartości wychowawczych oraz zapisanie ich w dokumentach szkolnych nie jest zadaniem łatwym. Wynika to między innymi z faktu różnego pojmowania wartości w przyjmowanych opcjach ideologiczno-politycznych, światopoglądach czy poszczególnych

${ }^{27}$ Zob. U. Ostrowska, Aksjologiczne podstawy wychowania, w: B. Śliwerski (red.), Pedagogika, t. I: Podstawy nauk o wychowaniu, Gdańsk 2006, s. 414.

${ }_{28}$ M. Łobocki, Wychowanie moralne, s. 19.

${ }^{29}$ Tenże, Wybrane, s. 125.

${ }^{30}$ Zob. Z. Marek, dz. cyt., s. 89-115. 
dyscyplinach naukowych (filozofia, teologia, pedagogika). Wiele trudności w określaniu wartości rodzi się w społeczeństwie pluralistycznym, w którym

trwa nieustannie walka o pozyskanie ludzi dla różnych wartości, nie zawsze zresztą zasługujących na bezwarunkową akceptację jako wartości społecznie i moralnie pożądane. Walkę tę toczą ze sobą ludzie o odmiennej orientacji filozoficznej, światopoglądowej i religijnej. Nie zawsze przyświecają im szlachetne cele. Nierzadko prowadzi się ją dla narzucenia innym swoich przekonań i wykazania swej wyższości lub zapewnienia sobie taniej popularności oraz płynących z tego rozmaitych gratyfikacji, łącznie z pieniężnymi ${ }^{31}$.

Pomijając trudne kwestie pojmowania i klasyfikacji wartości, można wskazać na pewne podstawowe i uniwersalne wartości, które są ważne dla szkolnego wychowania i winny znajdować się ponad wszelki podziałami. Są to wartości ,niezbędne dla rozwoju człowieka i stanowią fundament porozumienia społecznego, a co więcej, tworzą normatywny etos jednoczący wszystkie siły społeczeństwa dla realizacji dobra wspólnego" ${ }^{32}$. Autorzy różnie je formułują i klasyfikują. Przykładowo cytowany już wielokrotnie M. Łobocki wymienia altruizm jako wartość nadrzędną w wychowaniu moralnym i jeden z głównych celów wychowania. Wśród innych wartości wymienia rożnego rodzaju wartości podstawowe, duchowe i moralne, takie jak osoba ludzka wychowanka, poczucie odpowiedzialności, wolność, tolerancja, sprawiedliwość, miłość bliźniego, dobroczynność, nieszkodzenie i prawda ${ }^{33}$.

Wykazy konkretnych wartości odnajdujemy w podstawach programowych trwającej reformy oświaty. W podstawie programowej wychowania przedszkolnego oraz kształcenia ogólnego w poszczególnych typach szkół z 23 grudnia 2008 roku w odniesieniu do kształcenia w szkole podstawowej, gimnazjalnej i ponadgimnazjalnej stwierdza się, że szkoła realizuje zadanie „kształtowania u uczniów postaw warunkujących sprawne i odpowiedzialne funkcjonowanie we współczesnym świecie", natomiast w procesie kształcenia ogólnego szkoły

kształtują u uczniów postawy sprzyjające ich dalszemu rozwojowi indywidualnemu i społecznemu, takie jak: uczciwość, wiarygodność, odpowiedzialność,

${ }^{31}$ M. Łobocki, Wychowanie moralne, s. 79.

32 J. Mariański, Wartości jako przedmiot badań socjologicznych, w: H. Mielicka (red.), Socjologia wychowania. Wybór tekstów, Kielce 2000, s. 227.

${ }^{33}$ Zob. M. Łobocki, Altruizm a wychowanie, Lublin 2004; tenże, $W$ trosce, s. 68-83; tenże, Wychowanie moralne, s. 83-98. 
wytrwałość, poczucie własnej wartości, szacunek dla innych ludzi, ciekawość poznawcza, kreatywność, przedsiębiorczość, kultura osobista, gotowość do uczestnictwa w kulturze, podejmowania inicjatyw oraz do pracy zespołowej. W rozwoju społecznym bardzo ważne jest kształtowanie postawy obywatelskiej, postawy poszanowania tradycji i kultury własnego narodu, a także postawy poszanowania dla innych kultur i tradycji. Szkoła podejmuje odpowiednie kroki w celu zapobiegania wszelkiej dyskryminacji ${ }^{34}$.

\section{Wartość wychowania religijnego i chrześcijańskiego}

W niektórych cytowanych powyżej w wypowiedziach wychowywanie do wartości zostaje odnoszone w pewnych jego aspektach do pojęcia religii czy sacrum. Mówi się chociażby o człowieku, który tracąc oparcie w religii skłonny bywa do zagubienia się w wartościach. Dotykamy tutaj ważnej kwestii relacji pomiędzy procesem wychowania do wartości a rzeczywistością sacrum. Relacje człowieka do sacrum odgrywają w wychowaniu moralnym istotną rolę. Człowiek otwarty na sacrum wyraża gotowość przyjęcia i przestrzegania norm i praw podawanych przez sacrum i określających jego sens i treść postępowania ${ }^{35}$. Pomijanie roli wychowania religijnego w całym procesie wychowania człowieka jest niedopuszczalne. Wychowania religijnego bowiem „nie można oddzielać od zwykłych oddziaływań pedagogicznych” i jest ono „zakorzenione w całościowym rozwoju osobowości człowieka”36.

Warto w tym punkcie podkreślić wychowawczą wartość wiary chrześcijańskiej. W wierze chrześcijańskiej sacrum przyjmuje formę osobowej relacji z żywym Bogiem, która determinuje życie i postępowanie człowieka. $Z$ tej też racji religia chrześcijańska staje się cennym źródłem siły i inspiracji w procesie wychowania do wartości. W chrześcijaństwie wartości ogólnoludzkie odczytywane są w ścisłym odniesieniu do Boga. W chrześcijaństwie mamy do czynienia

z faktem Wcielenia Boga w naturę ludzką, złączenia wartości boskich i ludzkich. Mamy tu nie tyle przekaz pewnych teorii, lecz o wiele bardziej «Osobę Jezusa Chrystusa». W miejsce zaś jakiegoś systemu wartości mamy w Nim (w Chrystusie) «personalny symbol wartości» [...]. Chrześcijanie przyjmują więc «wartości ogólnoludzkie», ale poszukują ich jeszcze większej głębi, ich

${ }^{34}$ Rozporządzenie Ministra Edukacji Narodowej z dnia 23 grudnia 2008 roku w sprawie podstawy programowej wychowania przedszkolnego, zał. 2 i 4.

${ }^{35}$ Zob. Z. Marek, dz. cyt., s. 84-87.

${ }^{36}$ G. Hansemann, Wychowanie religijne, Warszawa 1988, s. 16. 
pełni i integralności, poszukują sensu przekraczającego ten, który zdolny jest nadać im człowiek ${ }^{37}$.

Wychowanie chrześcijańskie jest nie tylko procesem wzrastania w wierze, ale jest także procesem równoczesnego wzrastania w dojrzałości ludzkiej. Wymiar ludzki jest uznawany za fundamentalny czynnik wychowania chrześcijańskiego $^{38}$. Sobór Watykański II w Deklaracji o wychowaniu chrześcijańskim poucza, że prawdziwe wychowanie zawsze ,zdąża do kształtowania osoby ludzkiej w kierunku jej celu ostatecznego, a równocześnie do dobra społeczności, których człowiek jest członkiem i w których obowiązkach, gdy dorośnie, będzie brał udział" (DWCH 1) ${ }^{39}$. Wartości podkreślane w chrześcijaństwie mają więc ogromny potencjał wychowawczy. Religia chrześcijańska pozytywnie oddziałuje na rozwój całej osobowości człowieka. Jest to rozwój oparty na wartościach odczytywanych w kontekście Objawienia Bożego. Konkretne wartości chrześcijańskie wiążą się i utożsamiają z treściami wiary. Chodzi o prowadzenie życia ,wedle nowego człowieka w sprawiedliwości i świętości prawdy (Ef 4, 22-24)" i pomaganie „W chrześcijańskim kształtowaniu świata, dzięki któremu wartości naturalne włączone do pełnego rozumienia człowieka odkupionego przez Chrystusa przyczynią się do dobra całej społeczności” (DWCH 2). W tak rozumianym modelu wychowania chrześcijańskiego można dostrzec wiele różnych wartości. S. Kunowski opisuje je w następujący sposób:

ideologia wychowania chrześcijańskiego wprowadza w kształtowaniu i rozwijaniu ludzi ducha Chrystusowego, miłość dobra w powiązaniu ze wstrętem do zła, szacunek dla człowieka oraz apostolską aktywność wraz z czynnym miłosierdziem i współczuciem dla ludzkich potrzeb. Wychowanie takie przeobraża naturalnie egoistycznego człowieka i rozwija najlepsze strony jego istoty wewnętrznej ${ }^{40}$.

${ }^{37}$ M. Nowak, dz. cyt., s. 395.

38 Zob. G. Groppo, Educazione cristiana, w: J. M. Prellezo (red.), Dizionario di scienze dell'educazione, Torino 1997, s. 349.

${ }^{39}$ Sobór Watykański II, Deklaracja o wychowaniu chrześcijańskim Gravissimum educationis, w: Sobór Watykański II, Konstytucje, Dekrety, Deklaracje, Poznań 2002 - w tekście DWCH z odnośnym numerem.

${ }^{40}$ S. Kunowski, Podstawy współczesnej pedagogiki, Warszawa 2001, s. 104. 


\section{Wyzwanie dla formacji nauczyciela - nauczyciel jako świadek wartości}

Nauczyciel powinien nie tylko wychowywać innych do wartości, ale również sam być świadkiem wartości. Tak sformułowana prawda winna kształtować proces formacji czy samodoskonalenia nauczyciela. Współczesna szkoła akcentuje potrzebę nieustannego rozwoju nauczyciela. Mówiąc o formacji i rozwoju nauczyciela, mam na uwadze nie tyle rozwój zawodowy, mający na celu przede wszystkim rozwój kompetencji ściśle zawodowych w zakresie wiedzy i umiejętności dydaktycznych, ale przede wszystkim rozwój całej jego osobowości. W Karcie Nauczyciela jest zapis, który nakłada obowiązek dążenia nauczyciela do pełni własnego rozwoju osobowego ${ }^{41}$. Pojęcie rozwoju osobowego czy osobowości nauczyciela jest zagadnieniem złożonym. O bogactwie treści w tym zakresie świadczy chociażby ukształtowanie się pedeutologii jako dziedziny wiedzy pedagogicznej. Osobowość nauczyciela jest bardzo różnie postrzegana i analizowana w poszczególnych jej cechach. Cechy osobowości nauczyciela mają duży wpływ na jego skuteczność dydaktyczną i wychowawczą. Wiele miejsca temu problemowi poświęcono $\mathrm{w}$ pedagogice $\mathrm{w}$ okresie dwudziestolecia międzywojennego ${ }^{42}$. Należy powiedzieć, że formułowane wówczas prawdy do dziś zachowują swoją aktualność i wartość. Bardzo znaczące są słowa jednego ze współczesnych pedagogów:

predyspozycje i cechy osobowości, notabene różnie przez różnych autorów interpretowane tak co do ich roli, jak i treści oraz zakresu składających się na nie elementów, poczynając np. od «miłości dusz ludzkich», a kończąc na «ujmujących właściwościach zewnętrznych», przesądzają niejednokrotnie o stosunku uczniów do nauki określonego przedmiotu w szkole, a nawet - po jej ukończeniu - o wyborze dalszego kierunku edukacji. [...]. Uczniowie zafascynowani osobowością dobrego nauczyciela widzą w nim godny naśladowania wzór i przejmują w konsekwencji wiele jego pozytywnych cech. I odwrotnie, nauczyciel mało ambitny, hołdujący rutynie, ograniczający swoją pracę do przekazywania uczniom gotowej wiedzy, nie pobudzi ich do intensywnego wysiłku,

${ }^{41}$ Zob. KN art. 6, pkt. 3.

${ }^{42}$ Nie sposób pominąc tutaj pierwszych refleksji wybitnych polskich pedagogów i psychologów, wśród których można wskazać na J. W. Dawida, Z. Mysłakowskiego, S. Szumana, S. Baleya i W. Okonia. Zob. W. Okoń (red.), Osobowość nauczyciela. Rozprawy. Wt. Dawida, Z. Mystakowskiego, St. Szumana, M. Kreutza, ST. Baleya, Warszawa 1962. 
nie zachęci do «wyjścia poza przeciętność», nie roztoczy nad nimi celów, do których warto i należy zmierzać ${ }^{43}$.

Podkreślanie wartości cech osobowości nauczyciela jest ważne, gdyż dzisiaj w kształceniu nauczycieli te treści nie zawsze właściwie wybrzmiewają. Często w kwalifikacjach pedagogicznych rodzi się pewien mit, który ,sprowadza istotę kwalifikacji pedagogicznych do instrumentalności technicznej, do fachowości na wzór zawodów technologicznych"44.

W kontekście wychowania do wartości należy podkreślić znaczenie osobowości nauczyciela konstruowanej wokół przyjmowanych i wyznawanych wartości etycznych i moralnych. Obok zadania poznawania wiedzy nauczyciel musi wcielać w życie podstawowe normy społeczno-moralne i estetyczne. Nauczyciel musi ucieleśniać w swoim życiu ideały prawdy, dobra i piękna. Nauczyciel chcąc uczyć innych, musi najpierw sam być dobrze wykształcony, i aby czynić innych dobrymi, sam musi być najpierw dobry. Duże znaczenie wychowawcze ma przykład postępowania moralnego ${ }^{45}$. Należy wciąż pamiętać, że dawanie dobrego przykładu jest jedną z najbardziej niezawodnych metod wychowawczych ${ }^{46}$. R. Guardini zauważa, że

nic nie ma ważniejszego dla rozwoju osobowości niż zetknięcie się z człowiekiem naprawdę wielkim, poddanie się wpływowi jego postaci. Ta wielka postać wryje się w pamięć, zacznie na nas oddziaływać, inspirować nas, będzie nam drogowskazem. Każdy powinien spotkać w życiu człowieka wielkiego formatu. Może to być człowiek, który będzie wielki w ludzkich kategoriach. A może to być święty, człowiek Boży ${ }^{47}$.

Również nauka Kościoła mocno akcentuje potrzebę dawania przykładu własnego życia i na tym mechanizmie buduje własny styl nauczania. Niezwykle cenne stają się tutaj słowa papieża Pawła VI, przypomniane przez Jana Pawła II w adhortacji Ecclesia in Europa: „człowiek współczesny

43 C. Kupisiewicz, Podstawy dydaktyki, Warszawa 2005, s. 153.

44 A. Ryk, Aksjologiczne podstawy kształcenia nauczycieli, w: A. Rumiński (red.), dz. cyt., s. 74 .

45 Zob. M. Łobocki, Wychowanie moralne, s. 21-23; zob. też A. Arska-Karyłowska, Kształtowanie zachowań prospołecznych u dzieci za pomocq modelowania, Wrocław 1982; K. Konarzewski, Podstawy teorii oddziatywań wychowawczych, Warszawa 1987.

46 M. Łobocki, Wybrane, s. 162.

47 R. Guardini, Wiarygodność wychowawcy, w: tenże, Bóg daleki, Bóg bliski, Poznań 1991, s. 236. 
«chętniej słucha świadków aniżeli nauczycieli; a jeśli słucha nauczycieli, to dlatego, że są świadkami»" (EE 49)

Przyjęte przez nauczyciela wartości i jego moralność są ważnym czynnikiem w uznaniu go za autorytet moralny ${ }^{49}$. Autorytet nauczyciela z punktu widzenia jego pracy dydaktycznej i wychowawczej można uznać za istotny warunek dobrego wychowania. Dzisiaj, zauważa M. Łobocki, rola autorytetu w wychowaniu jest przez niektórych niedoceniania i uważana za przeżytek w czasach demokracji i pluralizmu. Według tego pedagoga

nie ma chyba nic bardziej fałszywego niż przeświadczenie o zbędności doceniania autorytetów w wychowaniu, jakie może okazać się skuteczne w społeczeństwie demokratycznym i pluralistycznym. Właśnie w warunkach demokracji i pluralizmu docenianie autorytetu może odegrać pierwszorzędną rolę w wychowaniu. Chodzi tu przede wszystkim o to, aby poprzez jego docenienie nie zagubić wartości podstawowych, ogólnoludzkich. Te przecież nie mogą stanowić jedynie przedmiotu negocjacji czy uporczywych licytacji ani nie mogą być podawane do uznawania w wyniku głosowania ${ }^{50}$.

Cennym komentarzem i nauką dla tych rozważań o potrzebie wzorców i autorytetów są słowa Jana Pawła II skierowane do nauczycieli i wychowawców w Łowiczu w dniu 14 czerwca 1999 roku. Papież stwierdza:

podjęliście się wielkiego zadania przekazywania wiedzy i wychowania powierzonych wam dzieci i młodzieży. Stoicie przed trudnym i poważnym wezwaniem. Młodzi was potrzebują. Oni poszukują wzorców, które byłyby dla nich punktem odniesienia. Oczekują odpowiedzi na wiele zasadniczych pytań, jakie nurtują ich umysły i serca, a nade wszystko domagają się od was przykładu życia. Trzeba, abyście byli dla nich przyjaciółmi, wiernymi towarzyszami i sprzymierzeńcami w młodzieńczej walce. Pomagajcie im budować fundamenty pod ich przyszłe życie ${ }^{51}$.

Wreszcie bycie świadkiem wartości czy bycie skutecznym nauczycielem wymaga dobrego przygotowania pedagogicznego i nieustannego dalsze-

48 Jan Paweł II, Adhortacja apostolska Ecclesia in Europa, Wrocław 2003 - w tekście EE z odnośnym numerem.

${ }^{49}$ Zob. K. Kotłowski, Autorytet nauczyciela, w: W. Pomykało (red.), Encyklopedia pedagogiczna, Warszawa 1993, s. 37.

${ }_{50}$ M. Łobocki, Wychowanie moralne, s. 117.

${ }^{51}$ Jan Paweł II, Homilia w czasie Mszy św., w: Jan Paweł II, Pielgrzymki do Ojczyzny. Przemówienia, homilie, Kraków 2006, s. 1144. 
go ustawicznego rozwoju. Ciekawe i dające wiele do myślenia są spostrzeżenia M. Dziewieckiego:

podstawową przyczyną obserwowanej obecnie bierności i bezradności szkoły w mierzeniu się z problematycznymi zachowaniami uczniów są poważne słabości i luki w przygotowaniu zawodowym nauczycieli. Po pierwsze, brak jest weryfikacji i formacji osobowości tych, którzy aspirują do roli pedagoga. W trakcie studiów weryfikowana jest wyłącznie wiedza poszczególnych studentów, ale nie ich stopień dojrzałości i odpowiedzialności. Tymczasem wiemy, że wychowanie dokonuje się głównie przez obserwację i naśladowanie zachowania osób dorosłych ${ }^{52}$.

Bycie świadkiem wartości wymaga także dobrej formacji permanentnej. W. Okoń stwierdza, że

tej fundamentalnej właściwości nauczyciela nie można jednak rozumieć statycznie, aby bowiem być dobrym nauczycielem-wychowawca, trzeba stale wzbogacać własną wiedzę o świecie a zarazem udoskonalać własny system wartościowania tego, co dobre oraz tego, co piękne. Tak więc tylko wówczas można mówić o dynamicznym rozwoju osobistych wartości danego nauczyciela, gdy zostanie w nim zaszczepione - przez innych lub przez niego samego stałe dążenie do stawania się mądrzejszym, lepszym, wrażliwszym na prawdę, dobro i piękno, a zarazem do czynienia innych takimi ${ }^{33}$.

\section{Zakończenie}

Dokonana refleksja wpisuje się w bogaty obszar poszukiwań pedagogicznych nad osobą nauczyciela i jego misją wychowawczą w szkole. $\mathrm{Z}$ pewnością zarysowane powyżej kwestie to zaledwie próba wskazania prawdy, że proces wychowania do wartości znajduje się u podstaw wychowania człowieka, nie jest łatwy w realizacji i tym samym wymaga ciagłych refleksji i poszukiwań. W poszukiwaniu dróg jego doskonalenia warto spojrzeć na osobę i misję nauczyciela. Nie jest to jedyny czy najważniejszy czynnik warunkujący poprawę wychowawczej misji szkoły, niemniej jednak nie należy go pomijać. Tę prawdę wyraża mądra obserwacja W. Okonia, według której „wiele warunków składa się na dobre wychowanie, lecz jeden wśród nich jest szczególny: doskonałe wychowanie może być dziełem tylko dosko-

${ }^{52}$ M. Dziewiecki, Szkoła a trudności wychowawcze, „Wychowawca” 11 (2004), s. 4.

53 W. Okoń, Wszystko, s. 247. 
nałego wychowawcy"54. Nauczyciel winien jak najmocniej utożsamiać się ze swoją misją i wciąż wymagać od siebie. Uczniowie potrzebują dobrych i mądrych nauczycieli, którzy będą przekazywać wartości i dawać o nich świadectwo. Wobec wielu trudnych sytuacji dzisiejszej szkoły warto wciąż ożywiać najbardziej wewnętrzne motywacje pracy każdego nauczyciela, aby pomimo codziennych kryzysów i niepowodzeń mógł on jak najlepiej realizować swoją wychowawczą misję. Praca nauczyciela, niezależnie od tego czy ją nazwiemy powołaniem, czy zawodem, stanie się mało skuteczna, jeśli zabraknie ducha poświęcenia, miłości i nauczycielskiej pasji. W powrotach do tych najgłębszych duchowych motywacji można wiele zyskać dla dzieła szkolnego wychowania.

\section{Educational and Axiological Aspects of the Teacher's Mission (Summary)}

The subject is part of a broader context of reflection on values-based education in Polish schools. The problem is presented as a very current and important issue. The author assumes that today there is a strong need for concern for the educational function of schools, which seems to be in crisis. This kind of opinion can be seen in several places of the text. The article can be viewed as a kind of contribution towards the reflection on the need for values in education. The subject of values is analysed in relation to certain aspects of educational reality. First, the focus is on the the important role of the educational and formative dimension of schools. The author concludes that schools' mission is not limited to teaching but should also include educating and nurturing. He notes that the educational function of schools is not easy to implement. Among various difficulties, he mentions the influence of ideology and politics. Next, the issues of education based on values, especially the moral and social values, are presented. The author emphasizes the great influence of religious pedagogy and Christian education. Finally, the last point discusses how important it is for teachers to personally exemplify values. The final conclusion of the reflection leads us in the following direction: one of the main factors for the effectiveness of values-based education is the attitude and conduct of teachers.

54 Tamże, s. 239. 